\title{
Charles Taylor's Critique of the Idea of Distributive Justice in Contemporary Political Philosophy
}

\author{
Iqbal Hasanuddin \\ Binus University, Jakarta \\ iqbal.hasanuddin@binus.ac.id
}

\begin{abstract}
Charles Taylor is a Canadian Philosopher who is very critical to the idea of distributive justice from the liberal thinkers. One of them is John Rawls, especially his thought in A Theory of Justice. Then, this paper will examine Taylor's view on that idea. To do so, I analyze Taylor's Philosophy and the Human Sciences. Following Aristotelian way of thinking on the importance of society to achieve the human good, Taylor criticizes some basic assumptions which support the liberal idea of justice. For him, the emergence of the idea of distributive justice is caused by the failure of the modern thinkers to understand the essence of human being and its relation to society.
\end{abstract}

Keyword: Charles Taylor, Distributive Justice, Communitarians

\begin{abstract}
Abstrak: Charles Taylor adalah seorang faylasuf politik asal Kanada yang dikenal sangat kritis terhadap gagasan keadilan distributif yang disampaikan oleh para pemikir liberal. Di antara pemikir liberal yang dijadikan sasaran kritiknya itu adalah John Rawls, khususnya pemikirannya yang tertuang di dalam A Theory of Justice. Dengan latar belakang demikian, makalah ini bertujuan untuk mengkaji pandangan Taylor tentang keadilan distributif tersebut. Untuk itu, penulis melakukan analisis tekstual terhadap tulisan Taylor yang berjudul Philosophy and the Human Sciences. Dengan berpijak pada corak berpikir Aristoteles yang menekankan pentingnya komunitas politik bagi pencapaian tujuan hidup manusia, Taylor membantah asumsiasumsi dasar yang melatarbelakangi gagasan liberal tentang keadilan distributif. Baginya, munculnya gagasan keadilan distributif di dalam filsafat politik kontemporer adalah buah dari kegagalan para pemikir modern dalam memahami hakikat manusia dan kaitannya dengan masyarakat.
\end{abstract}

Kata Kunci: Charles Taylor, Keadilan Distributif, Komunitas. 


\section{Introduction}

The issue of distributive justice is one of major themes of contemporary political philosophy. Moreover, since the publication of A Theory of Justice by John Rawls in $1971^{1}$, the issue has been debated, primarily by the liberal philosophers like Rawls himself, Robert Nozick ${ }^{2}$, Ronald Dworkin $^{3}$ and the communitarian philosophers like Charles Taylor, Michael Sandel $^{4}$ and Michael Walzer. ${ }^{5}$ This debate involves the nature and scope of distributive justice. In turn, this debate occurs not only in the field of philosophy, but also in that of public policy in many countries.

The questions are what is distributive justice? How do the liberal thinkers such as Rawls view justice? How do the communitarian thinkers like Taylor criticize that liberal view of justice? What are the different presumptions between both schools of thought in contemporary political philosophy? How do the liberals and the communitarians understand on the nature of human being and its relation to society?

This paper will discuss Taylor's response to Rawls' Theory of Justice based on his thought in the eleventh chapter of Philosophy and Human Sciences: Philosophical Papers Volume 2, "The Nature

1 John Rawls, A Theory of Justice (London: Oxford University Press, 1971). For introduction to Rawls' Thought in Bahasa Indonesia, see, Iqbal Hasanuddin, "Keadilan Sosial: Telaah atas Filsafat Politik John Rawls," in Jurnal Kajian Agama dan Filsafat Refleksi, Vol. 17, No.2, November 2018."

2 See, Robert Nozick, Anarchy, State and Utopia (New York: Basic Book, 1981).

3 See, Ronald Dworkin, A Matter of Principle (London: Harvard University Press, 1985).

4 See, Michael J. Sandel, Liberalisme and the Limits of Justice (Cambridge: Cambridge University Press, 1982).

5 See, Michael Walzer, Spheres of Justice: A Defence of Pluralism and Equality (Oxford: Oxford University Press, 1983). and Scope of Distributive Justice". In this paper, I want to examine the idea of distributive justice according to Charles Taylor. ${ }^{6}$ Inspired by Aristotelian political philosophy, Taylor criticizes the atomist views of distributive justice which have been supported by Locke and Nozick, the liberalegalitarian view of Rawls and the Marxian Views.

This paper is organized as follow. In first part, I describe Taylor's short biography and his position in the contemporary political debate as part of the communitarian thinkers. Then, I elaborate how Taylor differs between the Aristotelian social view and the Lockeian atomist view. Then, it is followed by analyses of his elaboration of the social context of the issue of distributive justice. Then, after clarifying Taylor's opinion about the four major streams in contemporary political philosophy including his republican perspective, this paper will be closed by conclusion and comments.

\section{Charles Taylor and the Communitarian Critique of Liberalism}

Charles Margrave Taylor is born in Montreal on November 5, 1931. He was raised in a bicultural and bilingual family with a Protestant, English-speaking father and a Roman Catholic, Francophone mother. After completing an undergraduate degree in history (1952) at McGill University in Montreal, Taylor earned a second bachelor's degree in politics, philosophy, and economics (1955) at Balliol College at the University of Oxford. He was awarded a doctorate in philosophy at Oxford in 1961. Most of

\footnotetext{
${ }^{6}$ It is based on Charles Taylor, Philosophy and the Human Sciences: Philosophical Papers, Vol. II (Cambridge: Cambridge University Press, 1985), especially chapter of "The Nature and Scope of Distributive Justice", 289-317.
} 
Taylor's academic career was spent at McGill and Oxford. He held the Chichele Professorship of Social and Political Theory at Oxford and then become a professor emeritus at McGill University. ${ }^{7}$

Taylor is a Canadian philosopher who has concern in a wide range of philosophical areas: Moral theory, theories of subjectivity, political theory, epistemology, hermeneutics, the philosophy of mind, the philosophy of language, aesthetics, and religion. ${ }^{8}$ In those philosophical areas, he writes many works that make him famous around the world. Most of his great philosophical ideas can be read in Hegel (1975), Hegel and Modern Society (1979), the Sources of the Self (1989), and A Secular Age (2007). He also writes some articles which then are published as books in Philosophy and Human Sciences (Volume 1 and 2).

In his Hegel (1975) $)^{9}$ and Hegel and Modern Society (1979), ${ }^{10}$ Taylor does a comprehensive study of the philosophy of Hegel. Especially, he places Hegel's position in the history of modern ideas, and his relevance and importance for our society today. Besides, Taylor also elaborates the key concepts of Hegel Philosophy such as the dialectics of being, nothing and becoming, and then spirit, consciousness, subjectivity, rationality, morality, society, state, history, and so on. In short, he engages with Hegel sympathetically, on Hegel's own terms in detail. So, what is the different between Hegel and Hegel and Modern Society? The two

\footnotetext{
${ }^{7}$ Ruth Abbey, "Charles Taylor" in Encyclopedia Britannica (http://www.britannica.com), read in December 30, 2019.

${ }^{8}$ Ruth Abbey, "Charles Taylor".

${ }^{9}$ Charles Taylor, Hegel (Cambridge: Cambridge University Press, 1975).

10 Charles Taylor, Hegel and Modern Society (Cambridge: Cambridge University Press, 1979).
}

books are the study about Hegel's philosophy. The first book is the long version, while the second is the short version. The second is the essential summary of the first.

In his book, The Sources of the Self (1989), ${ }^{11}$ Taylor studies on what makes the identity of modern individuality. This book involves discussions about identity and the good, inwardness', the affirmation of ordinary life, the voice of nature, and subtler language. His idea in The Sources of Self is coloring all his other writings in many areas. His thinking on distributive justice is also shown through his idea of sources of self. Some commentators see this book as Taylor's Magnum Opus.

In his A Secular Age (2007), ${ }^{12}$ Taylor engages himself in 21 st-century debates about the role of religion in modern Western societies. This book studies some of the major changes in Christian belief in Western societies in the last several centuries. The study examines how the modern individuals understand themselves, their society, and the natural world in a purely secular way without reference to the divine or to a religious realm. In the last five centuries, as Taylor says, the "social imaginary" of modern people stands in contrast to the condition that existed in 1500 and before, when the idea of God was very central in all areas of social and political life.

In his Philosophy and Human Sciences: Philosophical Papers 2,13 Taylor confronts John Rawls' Theory of Justice. ${ }^{14}$ Taylor

\footnotetext{
${ }^{11}$ Charles Taylor, The Sources of the Self: The Making of Modern Identity (Boston: Harvard University Press, 1989).

12 Charles Taylor, A Secular Age (Boston: Harvard University Press, 2007).

13 Charles Taylor, Philosophy and Human Sciences: Philosophical Papers 2.

${ }^{14}$ Rawls, A Theory of Justice.
} 
argues that Rawls had mistakenly defined justice in a non-anthropocentric way so it is only discussed on an epistemological level as if the meaning of justice were universally the same. Justice cannot be viewed as universally the same as if it is something unhistorical and unsocial because fundamentally, we could not view people as an atomistic subjectivity but holistic subjectivity. Together with Alasdair MacIntyre, Michael Walzer and Michael Sandel, Taylor are associated with a communitarian critique of liberal theory's understanding of the "self". Following Aristotle and Hegel, Communitarians emphasize the importance of social institutions in the development of individual meaning and identity.

According to Will Kymlicka in his Contemporary Political Philosophy, the communitarians offers the idea of 'constitutive ends' and 'the embedded self' as alternative to the liberal belief of rational subjectivity who can revise, question, or even reject, the traditions and practices of his society. So, the communitarians like Taylor urge a social context for individual freedom. This means that the communitarians also concern about the idea of freedom like the liberals do, but the communitarians see the importance of society to exercise that freedom. For the communitarians, without society, the idea of freedom only becomes a jargon. $^{15}$

\section{The Notion of Human Dignity behind the Principles of Distributive Justice}

Taylor starts his analyses on the issue of distributive justice by asking a question as follows: what kind of good is distributive

15 Will Kymlicka, Contemporary Political Philosophy: An Introduction (Second Edition), (Oxford: Oxford University Press, 2002), 271. justice? Asking this question shows us that he is one of the communitarian thinkers who hold that justice is a kind of the good life which people try to seek. It also presupposes that for him there is another kind of good outside the principles of distributive justice. ${ }^{16}$

To answer this question, Taylor refers to Rawls' formulation of circumstances of justice. As Taylor says, Rawls views that the separated human being collaborating in conditions of moderate scarcity is circumstances for justice, especially distributive justice. Then, is that distributive justice also relevant to other circumstances? ${ }^{17}$

Taylor invites us to consider a different circumstance that is the case of two nomadic tribes meeting in the desert; there are quite independent human beings, not bound together by any society or collaborative arrangement. In this condition, according to Taylor, there are very old and long-standing intuitions about justice which tells us as follow: it is wrong (unjust) for one to steal the flocks of the other. It is obvious that the proviso here is simple: we have a right to what we have. ${ }^{18}$

Although there is proviso saying "we have a right to what we have", one tribe has natural duty to help another tribe when the latter is starving. If the former refuses to help, the latter could legitimately steal from the former. Another way of stating this is that the starving tribe could take over what the other tribe has when it refuses to help. ${ }^{19}$

Taylor takes the case of tribes above as exemplars of men or people in what is called the State of Nature. The basic point here is that there no such thing as distributive justice

\footnotetext{
${ }^{16}$ Taylor, The Nature and Scope..., 289.

17 Taylor, The Nature and Scope..., 289.

18 Taylor, The Nature and Scope..., 289.

19 Taylor, The Nature and Scope..., 290.
} 
in the State of Nature. In Taylor's opinion, the proviso saying "we have a right to what we have" above is not a principle of distributive justice presupposing that men are in some kind of collaborative arrangement. Then, 'acting according to the natural duty is not the same thing as acting according to justice'. ${ }^{20}$

For Taylor, this raises another question: in what way do the principles of distributive justice differ from those of justice among independent agents, namely, agents in the State of Nature? And what is about human society that makes the difference? Even not recognized as a question by many thinkers, that question is claimed by Taylor as the fundamental one. The right answer to the question would make the issue of distributive justice increasingly clear for us. ${ }^{21}$

Taylor holds that there is an implicit presupposition in the principles of distributive justice: the Kantian term of human dignity. By virtue of this human dignity, human beings enjoy the status which animals and plants don't. Human being is beings who demand certain respect. Then, all human beings ought to be treated equally. Without giving respect and equal concern when we deal with someone, this means that we do not consider him or her as a human being. ${ }^{22}$

For Taylor, the problem is that there has been widespread disagreement on what human dignity consists in. This disagreement, in turn, has caused the disputes about the nature of distributive justice. The more the notion of human dignity is unexplored, the more the nature of distributive justice is unclear. Unfortunately, as Taylor notes, this discussion about human dignity has become

\footnotetext{
${ }^{20}$ Taylor, The Nature and Scope..., 290.

${ }^{21}$ Taylor, The Nature and Scope..., 290.

22 Taylor, The Nature and Scope..., 290.
}

disappeared in the Anglo-Saxon philosophical tradition since Seventeenth-century. ${ }^{23}$

To make the nature of distributive justice clear, according to Taylor, we have to clarify the notion of human dignity. Taylor suggests that our notion of human dignity is in turn bound up with a conception of the human good, that is, our answer to the question, what is the good man? What is the good human life? This also involves the questions about the relation between man and the society when realizing his good. In turn, this brings us to the ethical problem since Aristotle's time. ${ }^{24}$

In the following section, I will explore the different views of human subject between the Aristotelian Social View and the Lockeian Atomist View according to Taylor. In my own opinion, these differences are central to his critical examination about the nature and scope of distributive justice. While criticizing the Lockeian atomist view about human subject and its implications to the notion of justice, Taylor offers the concept of justice based on the Aristotelian notion of human beings as zoonpolitikon (social animal).

\section{The Differences between the Social View and the Atomist View}

Taylor elaborates a number of the differences between the social view and the atomist view. These differences involve the notions of the human good, the human dignity, the principles of justice and some arguments for the principles of justice. Some contrasts of them will be best viewed as follow.

The first is the notion of human good. Taylor argues that in the atomist view it is possible for human being to attain human

\footnotetext{
23 Taylor, The Nature and Scope..., 291.

${ }^{24}$ Taylor, The Nature and Scope..., 291.
} 
good without the existence of association or community. Why? The atomist view holds that the function of association or community is just to give some aids needed in realizing the human good. For example, association is needed to protect human being against attacks. In other words, for the atomist view, association has just an instrumental, not substantial function. ${ }^{25}$

By contrast the social view argues that association has a substantive role in realizing the human good. It is very implausible to attain the good without the existence of association or community. To put the issue in the Taylor's term, for the social view believes that 'the essential constitutive condition of seeking the human good is bound up with being in society'. For the social view, then, the function of association or community is not only instrumental to give some aid, but also substantial to make seeking the good possible for human being. ${ }^{26}$

Putting himself in the proponents of the social view, Taylor also claims that 'man cannot even be a moral subject, and thus a candidate for the realization of the human good, outside of a community of language and mutual discourse about the good and bad, just and unjust'. For Taylor and the other opponents of the social view, there is no seeking the good without a kind of community. The existence of community, thus, is the condition of possibility in realizing the human good. ${ }^{27}$

The second is the notion of human dignity. To restate Taylor's way of putting the issue, both the atomist view and the social view have their respective notions of human dignity based on the different notions of

\footnotetext{
25 Taylor, The Nature and Scope..., 292.

26 Taylor, The Nature and Scope..., 292.

27 Taylor, The Nature and Scope..., 292.
}

human good. For the atomist view, human dignity is quite independent of society. So, it is possible for the atomist like Locke to ascribe rights to man alone outside of society, namely, in the State of Nature. As a contrast to this atomist view, the social view suggests that human dignity is really bound up in some form of society. Thus, there is no possibility to realize human dignity outside of society. ${ }^{28}$

The third is the principles of justice. Taylor sees the atomist view ascribing the principles of justice from the aims of association. In this case, Taylor considers Lockeian view as an example. For Locke, the aim of the establishment of association is to preserve property including life, liberty and estate. Because all people who enter the association freely want to get benefit from it, there should be a principle assuring all members can fulfill equally their respective goals of life. Thus, there should be the principle of equal fulfillment. Unless there is this principle, people actually have no reasons to join the association. Without this principle, they would possibly scarify themselves for others by getting less than they give. ${ }^{29}$

According to Taylor, the principles of justice endorsed by the atomist view like Locke presupposed that there are rights of man before entering the association. Those rights are alienable the association has to preserve. It is forbidden for the association and its members to violate those alienable rights, namely, the rights to life, liberty and estate. As Taylor notes, this presupposition also can be seen in Nozick's entitlement theory of justice. ${ }^{30}$

To paraphrase Taylor's view, the principle justice of the atomist view based on

\footnotetext{
${ }^{28}$ Taylor, The Nature and Scope..., 292-293.

29 Taylor, The Nature and Scope..., 293.

30 Taylor, The Nature and Scope..., 293.
} 
the equal fulfillment is a kind of the principles of distributive justice. These principles of justice of the atomist view require two things. Firstly, the benefit of the association has to be shared equally among its members. This benefit involves the opportunity to fulfill equally the aims of the members of the association. Secondly, the principles of distributive justice have a limit which is forbidden to transgress, that is the alienable rights involving the rights to life, liberty and estate. $^{31}$

As contrast to the principles which belong to the atomist view, Taylor argues that there is no kind of the principles of justice in the social view. Because the realization of human dignity is bound up with some form of society, there is no fixed framework for distribution applied to all form societies in all spatio-temporal conditions. In the social view, the framework for distribution can determined for a prevailing society by the nature of the common goods they seek. Thus, because there are so many forms of society in all times and around the world, the framework for distribution varies historically. ${ }^{32}$

Taylor adds this by saying that the members of society seeking the common good are all in each other's debt. While some people give their contribution to the common deliberative life of society, the others make sure its integrity. Although there should be the balance of mutual indebtedness among the members, it is not entirely reciprocal. In this condition, there are possibly people who deserve more than other because they are more in their debt than other. ${ }^{33}$

As I have noted, based on his elaboration above, we can see that Taylor

\footnotetext{
${ }^{31}$ Taylor, The Nature and Scope..., 293.

32 Taylor, The Nature and Scope..., 296.

${ }^{33}$ Taylor, The Nature and Scope..., 298.
}

does not believe that the principles of distributive justice have to be applied taken for granted. For Taylor, whether the principles are applied or not depend on the form of association or community. So, what he rejects is not the principles of distributive justice in itself, but the atomist view who believing that these principles have to be applied based on the notion of man alone without any considerations of the contexts of society. What is important for Taylor is not the principles themselves, but the form of society in which the members attempt to seek their good in common.

\section{The Context of Distributive Justice}

Before exploring Taylor's opinion on the issues of distributive justice in the perspectives of contemporary political philosophy, I will clarify its socio-political contexts. Fortunately, it is easy to do so because Taylor himself has tried to make it clear from the outset. Moreover, this clarification of its socio-political contexts is really important in the line of Taylor's argument.

Taylor argues that there are two areas arising constantly in the modern society. The first is the area of differentials which is the question of allowable differences between wages or income received for different kind of work. The second is an attempt in equalization policy involving redistribution of income or economic prosperity, or life opportunities by which transfer payments or special programs to develop certain regions, etc. This equalization polices have a significant correlation to the issue of distributive justice. ${ }^{34}$

While Taylor does not give a satisfying explanation to the question why there are so

${ }^{34}$ Taylor, The Nature and Scope..., 303. 
many aspirations to equality in modern society, he explains much more the historical background for that resistance to equalization. According to Taylor, it is easy for the comparatively better-off to refuse the politics of redistribution. What is important here is how he relates the refusal of redistribution to the process of privatization in the life of modern society. In his opinion, there is a common view generally accepted in Western industrial society that happiness and the good life can be attained by a man alone. Thus, society is only seen as an instrument, not as a locus in which human beings can develop their potentialities. ${ }^{35}$

Taylor holds that there is a tension between the attempt to equalization and its resistance. Consequently, at the same time, there is also tension between the proponents of politics of redistribution and its opponents. Both have different views and feelings on the policy of redistribution. For the proponents, the policy of redistribution is a must in order to make just society. On the contrary, the opponents see it as injustice because it has sacrificed the affluent. ${ }^{36}$

While made by politicians who are always interested in mass vote, the policy of redistribution is only possible by taxation of the affluent. Time by time, the cost of policy becomes more expensive. As a result, for the middle classes or the affluent paying tax more than other, redistributive policy seems to be in favor of the less endowed and the less hardworking. In turn, they feel a sense of grievance. Thus, they see it not only jeopardizing but also violating their property rights. At the end, they see and feel that policy is really unjust. ${ }^{37}$

\footnotetext{
35 Taylor, The Nature and Scope..., 304.

${ }^{36}$ Taylor, The Nature and Scope..., 306-307.

${ }^{37}$ Taylor, The Nature and Scope..., 307.
}

Taylor holds that this condition has given a climate for forms of reasoning about distributive justice to increase that are the atomist views. For him, one of the atomist views is the Lockeian atomist view. On this view, men had in State of Nature an independent capacity to exploit the natural resources and then to found property. When entering society, men need this society as an association which makes sure the safety of their property. As Taylor notes, of course now almost no one can believe this idea of State of Nature. Contrary, majority people in Western society believe that they are working within large and complex structure of society. ${ }^{38}$

Beside the Lockeian version, according to Taylor, there is also another atomist view which suggests that the individual is not seen as possessor of property, but as an independent being with his or her own capacities and goals. Thus, the aims of association are not to protect property as convinced by the Lockeian version, but to combine all individual capacities in order to make the resultant product more productive than each would be alone. Because the capacities of every individual vary, thus there should be the different shares among all individuals. Based on the principle of equal fulfillment, the individual who has useful capacities in collaboration with others in association or society ought to get a greater share of the product resulted. ${ }^{39}$

Taylor sees that the issue of contribution is very important in the latter atomist view above. How much someone gets the share of the resultant product is determined by a principle that is his or her contribution to association. Because of it, Taylor calls this the contribution principle.

\footnotetext{
${ }^{38}$ Taylor, The Nature and Scope..., 305.

39 Taylor, The Nature and Scope..., 305.
} 
According to Taylor, this contribution principle is the very bases of the principles of distributive justice embraced by the protagonists of the contemporary atomist view. Of course, the contribution principle is more sophisticated than the Lockeian version. And this is the reason why the contribution principle is more applicable in the context of distributive justice today. ${ }^{40}$

According to Taylor, this contribution principle lies behind the resistance to the policy of redistribution. As noted above, the more the individual gives contribution to society by his or her capacities, the more he or she gets share of product; on the contrary, the less he or she gives contribution, the less he or she gets share of product. Based on this contribution principle, there is an intuition about relative value of doctors, lawyers, ship pilot, and so on deserving high income. So, they consider themselves as people who have justified differential remuneration.

\section{Main Streams in Contemporary Political Philosophy}

Regarding the issue of redistributive policy or of distributive justice, Taylor has explained two kinds of atomist views which are respectively ascribed to John Locke and Robert Nozick. Then, He adds this by two other main streams in contemporary political philosophy that are Marxists and the liberalegalitarian which ascribed to John Rawls. While giving a critical examination to those four major streams, Taylor tries to offer the republican political thought as an alternative.

In presenting Rawls' idea of distributive justice, Taylor does not give any comments too much. He just suggests that Rawls has answered the wrong question. For Taylor, Rawls has established a sort of principles of

${ }^{40}$ Taylor, The Nature and Scope..., 305. justice without considering historical and cultural variations in the kinds of association to address and of the goods to seek. Indeed, Taylor argues that Rawls put his theory of justice in the context of 'the social union of social union' and then interpreted as the mutual involvement in society. Taylor also holds that Rawls tries to address the common good consisting of (a) equal liberty and (b) the more far-reaching equality. ${ }^{41}$

Although Taylor does not consider Rawls' theory of distributive justice as a kind of atomist view, he rejects Rawls' theory because of its tendency to egalitarianism which more than what now American practices. Taylor indicates this egalitarianism by showing that Rawls' idea of the difference principle 'represents an agreement to regard the distribution of natural talents as a common asset and to share in the benefits of this distribution whatever it turns out to be'. For Taylor, this Rawls' egalitarianism is contrary to the view of man and society presupposed by the contribution principle. Thus, Taylor believes that the proponents of the contribution principle have some objection which Rawls could not answer. ${ }^{42}$

Taylor also puts Marxists in the proponents of egalitarianism like Rawls with the greater tendency. But, for Taylor, Marxian political philosophy does not have something to do with the idea of distributive justice. This is really plausible because Marxists just concerns to the issue of production, not distribution. For Marxist, the truly justice can only be attained in a classless society. So, further examination to Marxian political philosophy is considered by Taylor irrelevant. $^{43}$

\footnotetext{
${ }^{41}$ Taylor, The Nature and Scope..., 308.

42 Taylor, The Nature and Scope..., 308.

43 Taylor, The Nature and Scope..., 307-308.
} 
Then, Taylor tries to show the basis error of the atomist views. For him, the main problem is not its idea of individuality itself but that of atomism. In this way, the atomist views 'fail to consider that the free individual with his own goals and aspirations is only possible with a certain civilization'. At this point, Taylor holds that the modern individual is a product of certain context of society which endorses it by its rule of law, its rule of equal respect, and so on. Without these, the very individuality in modern society is impossible. $^{44}$

Especially, Taylor points out the idea of liberty to show the existence of society as a context to seek the good that is liberty. To exercise liberty, we need not only liberty in our mind, but also the social condition supporting it. For Taylor, this social context is really important to realize liberty. So, this view suggests the social view that liberty as a human good can only be attained in a certain form of society in which liberty is bound up. ${ }^{45}$

Taylor also talks about the opinion of defender of a mitigated contribution principle arguing that there is not only liberty as the good to seek, but also the other goods such as honor, prosperity and so on. At this point, society does not only have to protect liberty of its members, but also to serve prosperity and honor. According to Taylor, it means that each view of main streams in political philosophy corresponds to a dimension of contemporary social life.

Consequently, Taylor claims, that the contemporary society cannot be understood within the frames of a single theory of distributive justice. In economic field, there is possible to set a theory of distributive justice, not only between two parts in a state, but also

${ }^{44}$ Taylor, The Nature and Scope..., 309.
45 Taylor, The Nature and Scope... 310. among all parts around the world; in the cultural field, there is also possible to establish a theory of distributive justice in the framework of multiculturalism. Because of this reasons, according to Taylor, we have to abandon the search for a single set of principles of distributive justice.

Is the fact of complexity and multidimensionality of the issue of distributive justice problematic? For sure, Taylor says: no problem at all. For Taylor, it seems like what emerges in the Aristotle's discourse of justice. Quoting Aristotle saying, Taylor says that 'those who adopt a single exclusive principle speak of a part of justice only'. Then, Taylor closes his critical examination on the issue of distributive justice by saying about the republican society. The common citizenship of that republican society requires as follows: the first is a certain degree of equality; and the second is the balance of mutual indebtedness.

\section{Conclusion and Comments}

Before concluding and giving some comments, let me first summarize the main point of this paper. For Taylor, there are two views of the nature of distributive justice those are the social view and the atomist view. There are a number of the differences between the social view and the atomist view. These differences involve the notions of the human good, the human dignity, the principles of justice and some arguments for the principles of justice.

According to Taylor, the atomist view holds that it is possible for human being to attain human good without the existence of association or community. Why? The atomist view sees that the function of association or community is just to give some aids needed in realizing the human good. For example, 
association is needed to protect human being against attacks. In other words, for the atomist view, association has just an instrumental, not substantial function.

By contrast the social view argues that association has a substantive role in realizing the human good. It is very implausible to attain the good without the existence of association or community. To put the issue in the Taylor's term, for the social view believes that 'the essential constitutive condition of seeking the human good is bound up with being in society'. For the social view, then, the function of association or community is not only instrumental to give some aid, but also substantial to make seeking the good possible for human being.

Putting himself in the proponents of the social view, Taylor also claims that 'man cannot even be a moral subject, and thus a candidate for the realization of the human good, outside of a community of language and mutual discourse about the good and bad, just and unjust'. For Taylor and the other proponents of the social view, there is no seeking the good without a kind of community. The existence of community, thus, is the condition of possibility in realizing the human good.

Then, Taylor has elaborated the four main streams in contemporary political philosophy debating over the scope of distributive justice. Those are atomist views which are respectively ascribed to John Locke and Robert Nozick, Marxists and the liberalegalitarian which ascribed to John Rawls. While giving a critical elaboration to those four major streams, Taylor tries to offer the republican political thought as an alternative. He considers himself as a republican philosopher.
Talking as a republican philosopher, Taylor holds that the contemporary society cannot be understood within the frames of a single theory of distributive justice. So, according to Taylor, we have to abandon the search for a single set of principles of distributive justice. Then he ends talking on the issue of distributive justice by saying about the republican society. For him, the common citizenship of that republican society requires as follows: the first is a certain degree of equality; and the second is the balance of mutual indebtedness.

Then now let me give some critical comments on Taylor's thinking on the issue of distributive justice. Firstly, in my opinion, Taylor has not concerned with the idea of distributive justice itself as thought by thinkers like Rawls and Nozick. What he has concerned is the ontological presupposition behind its idea. Thus, it can be said that the focus of Taylor analyses is not the content of distributive justice, but the context of it. Who wants to get, for example, a deep interpretation on Rawlsian and Nozickian ideas of distributive justice according to Taylor would be disappointed. In his analyses above, we cannot get his normative critics to both Rawls and Nozick.

Secondly, I see that it is unclear whether Taylor put Rawls in the proponents of atomist views or not. It seems for me that he put Rawls outside of the proponents of atomist views. Taylor says:

"Perhaps the fullest description of this society is to be found in section79 of A Theory of Justice, where Rawls describes it as 'the social union of social unions.' If this Humboldtian vision were correct about the nature of our mutual involvement in society, 
and the kinds of common good we seek, then indeed, (a) equal liberty would be an essential background feature (and hence would have priority) and (b) we would be bound to accept the more farreaching equality Rawls prescribes. $" 46$

So, does it mean that Rawls holds the social view? It is still not clarified.

Thirdly, I suggest that Taylor's political philosophy echoes not only Aristotelian republican way of thinking, but also the Hegelian Sittlichkeit. ${ }^{47} \mathrm{He}$ uses those two sources to criticize the liberal form of thought, especially its atomist presupposition. Of course, as the matter of content of normative thought, there is no sharp contrast between Taylor and thinker like Rawls. But, Taylor tells us how we could give appropriate analyses to the social context before talking something normative like the issue of distributive justice. Then, although there is no an absolute novelty in Taylor's idea of distributive justice, there will be benefit to begin thinking philosophy from a certain context.

\section{Bibliography}

Abbey, Ruth, "Charles Taylor" in Encyclopedia Britannica (http://www.britannica.com).

Dworkin, Ronald, A Matter of Principle, London: Harvard University Press, 1985.

Hasanuddin, Iqbal, "Keadilan Sosial: Telaah atas Filsafat Politik John Rawls" in Jurnal Kajian Agama dan Filsafat

46 Taylor, The Nature and Scope..., 308.

47 See. Charles Taylor, Hegel and Modern Society (Cambridge: Cambridge University Press, 1979), 83-84.
Refleksi, Vol. 17, No.2, November 2018."

Kymlicka, Will, Contemporary Political Philosophy: An Introduction (Second Edition), (Oxford: Oxford University Press, 2002.

Nozick, Robert, Anarchy, State and Utopia, New York: Basic Book, 1981.

Rawls, John, A Theory of Justice, London: Oxford University Press, 1971.

Sandel, Michael J., Liberalisme and the Limits of Justice, Cambridge: Cambridge University Press, 1982.

Taylor, Charles, Hegel, Cambridge: Cambridge University Press, 1975.

--. Hegel and Modern Society,

Cambridge: Cambridge University

Press, 1979.

--------. "The Nature and Scope of Distributive Justice" in Charles Taylor, Philosophy and the Human Sciences: Philosophical Papers, vol. Ii, Cambridge: Cambridge University Press, 1985.

---------.The Sources of the Self: The Making of Modern Identity (Boston: Harvard University Press, 1989).

---------. A Secular Age, Boston: Harvard University Press, 2007.

Walzer, Michael, Spheres of Justice: A Defence of Pluralism and Equality, Oxford: Oxford University Press, 1983. 